\title{
Feminizm ve Görsel Tasarım: Birinci Kușak Feminizm Dönemindeki Kozmetik Reklamlarında Kadın İmgelerinin Dönüșümü
}

\author{
Eda Er Özden ${ }^{1}$
}

\section{Zafer Özden ${ }^{2}$}

Öz

Feminist hareket sosyo-ekonomik-politik ve kültürel alanlarda insanları ve toplumu derinden etkileyerek toplumsal değişim konusunda belli başlı güçlerden biri haline gelmiştir. Feminizm aynı zamanda kadınların, reklamlar da dâhil olmak üzere, kültürel ürünlerdeki temsili üzerine odaklanmasıyla hem kadınların maddi koşulları hem de toplumun kültürel yaşamı üzerinde değişimler yaratmıştır. Kadınlar hakkında toplum içinde egemen olan ve değişmekte olan düşünceleri yansıttıkları için reklamlar feministlerin en çokele aldıkları konulardan biri olmuştur. Kadınların reklamlardaki temsili ve feminizmin bu imgelerin görsel dönüşümü üzerindeki etkisi bizi temel bir durumla karşı karşıya getirmektedir: Kadınların sosyo-ekonomik-politik ve kültürel mücadeleleri belirli tarihsel dönemlerin toplumsal koşullarından ayrılamamaktadır. Reklamlardaki kadın imgeleri ise bu toplumsal koşullara bağlı bir biçimde on yıllık dönemler içinde hem görsel hem de metinsel olarak değişmektedir. Bu nedenle feminist hareketin dalgalarını tarihsel dönemleştirme için kullanmak ve kadın temsillerini bu dönemlerin toplumsal koşullarını göz önüne alarak çözümlemek işlevsel bir bakış açısı sağlamaktadır. Her bir feminist dalga -toplumun sürekli değişim içinde olan koşullarından ortaya çıkan farklı kuramsal ve pratik alanlarla ilgili zihinsel meşguliyetleriyle- kadının toplumsal koşullarının ve görsel temsillerinin üzerinde kendine özgü etkilerde bulunmuştur. 1800'lü yıllardan başlayarak 1960'lı yıllara kadar uzanan birinci dalga feminizm, ataerkiye karşı temel konuları ortaya koyduğu için belirli bir tarihsel öneme sahiptir. Bu çalışmanın amacı; birinci dalga feminizmin reklamcılık endüstrisi üzerindeki etkisini değerlendirmek ve dönemin kozmetik reklamları üzerine içerik ve görsel tasarım yönünden feminist bir bakış açısıyla nitel bir analiz gerçekleştirmektir.

Atıf: Er, Özden, E. ve Özden, Z. (2018). Feminizm Ve Görsel Tasarım:

Birinci Kușak Feminizm Dönemindeki Kozmetik Reklamlarında Kadın İmgelerinin Dönüșümü. Akdeniz Üniversitesi Iletișim Fakültesi Dergisi, (AKIL) Aralık (30), s. 142-163

1 Dr. Öğretim Üyesi, Ege Üniversitesi, Güzel Sanatlar, Tasarım ve Mimarlık Fakültesi, Görsel İletişim Tasarımı Bölümü.

2 Prof. Dr., Ege Üniversitesi, Güzel Sanatlar, Tasarım ve Mimarlık Fakültesi,, Görsel İletişim Tasarımı Bölümü. 
$\mathrm{Bu}$ analiz içinde, araştırmanın konusuna ve tarihsel dönemleştirmesine uygunluk gösteren ve dönemindeki cinsel işbölümüne ve kapitalist/ataerkil beklentilere karşı çıkan modern kadın temsilleri incelenecektir. Bu incelemede, toplumsal yapı içinde kadının değişen rolü sonucunda kozmetik reklamlarında yeni kadın temsillerinin ortaya çıktığı görülmüştür.

Anahtar Kelimeler: Feminizm, görsel tasarım, kozmetik reklamları, kadın temsili, toplumsal değişim

\title{
Feminism and Visual Design: Transformation Of Women Images In Cosmetics Advertisements In The First Wave of Feminism
}

\begin{abstract}
Feminist movement has affected people and society in a profound way through its impacts on the socio-economic-politic and cultural areas, and it has been one of the major forces for social change. It has also created changes both on the material conditions of women and the cultural life of society with a focus on women's representation in cultural products, including advertisements. Advertisements are one of the most debated topics by the feminists as they reflect the dominant and changing ideas of women in society. Due to the representation of women in advertisements and the effect of feminism on the transformation of these images we confront a main problem: the socio-economic-political and cultural struggles of women cannot be separated from the social reality of a given period. The images of women in advertisements change both visually and textually in decades, depending on these social conditions. Therefore, it would be a working method to use the waves of feminist movement for historical periodization, and to analyze the representations of women regarding the social conditions in this period. Each feminist wave had peculiar effects on social conditions and visual representations of women with different theoretical and practical concerns, stemming from ever changing conditions of society. The first wave of feminism has a particular historical importance as it presents the main concerns in the struggle against patriarchy from the late 1800s to the 1960s. The goal of this study is to evaluate the impact of the first wave of feminism on advertising industry, and to make a qualitative analysis of the advertisements in the given period, discussing the text and visual design of the cosmetic advertisements from a feminist perspective. In this analysis, the choice of sample advertisements will be guided by the content and the periodization of the study, and cosmetic advertisements showing modern women representations against sexual labor division and capitalist/patriarchal expectations will be taken into consideration. It has been noticed that new women representations emerged in cosmetic advertisements as a result of the changes in the role of women in the social structure.
\end{abstract}

Keywords: Feminism, visual design, cosmetic advertisements, woman representation, social change 


\section{Giriș}

$\mathrm{K}$ adın hareketlerinin paralelinde gelişen feminist hareket, yirminci yüzyılda toplumsal cinsiyet alanında yaşanan toplumsal değişimler üzerinde dikkate değer bir etkiye sahip olmuştur ve yalnızca toplumun maddi yaşamı üzerinde değil, aynı zamanda kültürel yaşamı ile ilgili alanlarda da dönüştürücü etkiler yaratmıştır. Yüzyılı aşan dönüştürücü tarihiyle birlikte feminizm, kadının toplumsal yaşam içindeki değişen konumuna paralel bir şekilde kültürel üretimlerde de kadın temsillerinin değişmesine hem kuram hem uygulama düzeyinde katkıda bulunmuştur.

Kadın toplumsal cinsiyetinin kapitalist ataerkil ideoloji doğrultusunda yeniden üretilmesinde en büyük paya sahip olan kurumlardan biri olan reklamcılık da bu etkinin dışında kalmamıştır. Bilindiği gibi, reklamların en önemli ideolojik işlevlerinden biri, tüketicilere belirli toplumsal cinsiyet ve toplumsal statü konumlarını önermektir. Belirli ürün gruplarında bu konumlandırmalar esas olarak duygulara seslenecek şekilde ve bilinçaltına yönelik kültürel imgelerin kullanılmasıyla yapılandırılmaktadır. Feminist hareketler farklı dönemlerde farklı düzeyde sahip oldukları belirleyici etkileriyle kadının reklamlardaki toplumsal cinsiyet ve toplumsal statü ile ilgili temsillerinin görsel tasvirleri üzerinde büyük etkide bulunmuşlardır.

Bu etkininin başlangıcı ilk kuşak feminist döneme tarihlenmektedir. 1800'lü yılların sonlarından 1960'ı yıllara dek tarihlenen birinci kuşak feminizm içinde geleneksel kadın temsillerinden ayrılan yeni kadın imgeleri, diğer kültürel alanlarda olduğu gibi genel olarak reklamlarda özel olarak ise kozmetik reklamlarında yer almıştır. Bu nedenle bu reklamlar kadının toplum içindeki dönüşümünü yansıtan görsel tarih ürünleri olarak önem taşımaktadır ve reklamcılık da kadınların tarihini yazmak için özel bir alan olarak önem kazanmaktadır.

Bu yönüyle reklamcılık yalnızca belirli bir mesleğe ait bir alan olarak değil, aynı zamanda toplumsal tarihe ait belirli olguları doğrudan ya da simgesel düzeyde yaratıcı bir görsel tasarım ile yansıtan bir alan olarak da değerlendirilmektedir. Reklamlar belirli ürünler aracılığıyla daha özgül konuların görselleştirilmesine olanak tanıdıkları gibi, reklam mesajının görsel tasarımı aracılığıyla içinde bulunulan tarihsel dönemin toplumsal dışavurumunu da sağlamaktadır. Bu yüzden reklamların tarihsel yönden ele alınmasıyla belirli kuramsal konuların özgül bir şekilde incelenmesini gerçekleştirebilmek mümkündür.

Toplumsal cinsiyet de bu türden konulardan biridir. Toplumsal cinsiyetin reklamlardaki sunumu konusundaki geniş literatür içinde, birçok akademik çalışma hem genel reklam örneklerinde hem de farklı türdeki ürünlerin ya da hizmetlerin reklam örneklerinde, toplumsal cinsiyet temsillerini reklam metni ve görsel tasarımı arasındaki ilişkiler bağlamında incelemiştir. Bu bakımdan genel olarak kitle iletişim araçlarındaki özel olarak ise reklamcılık gibi daha özgül alanlardaki kadın temsillerini inceleyen çalışmalar 
dikkate değer bir niceliğe ulaşmıştır. Feminist araştırmalar açısından da bu konu özel bir önem taşımaktadır. Özellikle moda ve moda ile ilişkili kozmetik gibi ağırlıklı olarak kadına yönelik sektörlere ait reklamlar verimli bir çalışma alanı olarak dikkat çekmektedir. Moda ve kozmetik reklamlarındaki kadın temsilleri ile ilgili olarak nitel ve nicel araştırmalardan oluşan geniş bir literatür bulunmaktadır. Bu çalışmanın amacı da bu literatüre bir katkı sağlamaktır.

\section{Reklamlardaki Kadın Temsilleri Üzerine Literatürün Gelișmesi}

Reklamlarda kadın temsilleri konusunu genel çerçevede ele alan yaygın bir literatür bulunmasına rağmen, reklamcılığın özgül alanlarına ve belirli tarihsel dönemlerine ilişkin çalışmalar da artış göstermektedir. İlk bakışta bu çalışmaların genel olarak reklamlar özel olarak ise belirli ürün grupları üzerine yapılmasının pek fazla bir fark yaratmayacağı düşünülebilir. Ancak reklamcıların incelikli mesaj stratejilerinin yarattığı etkiler bağlamında, farklı ürün gruplarında daha özgül medya mesajlarının tasarlanmasının hedef kitle üzerindeki etkisi açısından fark yaratacağı da hesaba katılmalıdır.

Kadının kitle iletişim araçlarındaki temsili üzerine en fazla çalışmayı yapan feminist kuramcılar ve yazarlar doğal olarak bu konudaki literatürün geniş bir kısmını üretmişlerdir. Tarihsel bir dönem olarak dikkat çekecek olursak, özellikle "altmış sonlarında yeniden doğuşundan itibaren, kadın hareketleri reklamcılığı toplumun en rahatsız edici kültürel ürünlerinden biri olarak seçmişti. Daha farklı ve daha az geleneksel kadın portreleri ortaya koymaları için reklam şirketleri üzerinde baskı oluşturmak üzere gözlem projeleri, tüketici boykotları ve diğer araçlar kullanılmıştı" (Zoonen, 2004, s.67). Ağırlıklı olarak bu dönemde ortaya çıkan ikinci kuşak feministlerin etkisindeki kadın hareketi, kadının reklamlardaki temsilini kapitalist ataerkil ideoloji hizmetindeki sunumu açısından ele alan ilk ciddi eleştirileri ortaya koyan çalışmalar üretmişlerdi. Bety Friedan'ın 1939-59 arasında kadın dergilerinde yer alan kadın imgesini inceleyerek tüketim kültürü içinde kadını ele alan The Feminine Mystique (1963) adlı kitabı, "Amerikan politik ve toplumsal tarihinin istikametini dönüştürmeye yardımcı oldu. Tarihçiler kitabın yayınlanmasını modern kadın hareketinin başlangıcı olarak işaret etmektedirler" (Horowitz, 1998, s.4). Friedan'ın ardından gelen feminist araştırmacılar da tarihsel bir bakış açısıyla kadın temsilini tüketim kültürü içinde incelemeye devam ettiler.

Günümüzde kadının toplumsal cinsiyetinin genel olarak reklamlardaki temsili üzerine geniş bir literatür bulunmaktadır ve feminist araştırmalar bu literatürün dikkate değer bir kısmını kapsamaktadır. Çalışmamız bu literatürün ortaya koyduğu kuramsal bakış açısı içinde, toplumsal değişime paralel bir şekilde gelişen feminist hareketin ilk dönemine denk gelen şekilde, geleneksel ev kadını temsillerinden ayrılan yeni kadın imgelerinin özel bir alan olarak kozmetik reklamlarında nasıl ortaya çıktığını ele alacaktır.

Kadının reklamlardaki temsilini ele alan feminist çalışmalar, dikkate değer bir biçimde üretilen kadın imgelerinin hem içerik hem görsellik üzerinden değişimi üzerinde dikkate değer bir etkide bulunmuştur. Kuşkusuz bu etki esas olarak toplumsal değişim sonucunda 
kadının elde ettiği yeni toplumsal konumlar sayesinde gerçekleşmiştir. Ama feminist kuramcıların ve yazarların çalışmalarının bu değişime büyük bir hız kazandırdıkları ve yaygınlaştırımalarına katkı sağladıkları unutulmamalıdır. Bu feminist çalışmalar kadın temsili ile ilgili sorunlara derinlikli bir şekilde kuramsal düzeyde yaklaşımasını ve bu konuda geniş bir bilgi birikimi elde edilmesini sağlamıştır. Her bir feminist kuşak ile birlikte, feminist kuramcılar ve yazarlar, bu birikim üzerinde kadının toplumsal cinsiyet temsilleri konusunda daha çeşitlenmiş düşünceler ortaya koymuşlar ve bu düşüncelerin ortaya çıkardığı yeni taleplerde bulunmuşlardır. Bu bakımdan feminist hareketin farklı dönemlerindeki kuramsal tartışmalar ve bunların yaratmış olduğu etki bağlamında, reklamlardaki görsel tasarım içinde kadın toplumsal cinsiyeti temsillerinin incelenmesi, hem feminist düşüncenin etkisinin hem de oluşmasına yardımcı olduğu toplumsal değişimin anlaşılmasına katkıda bulunacaktır.

\section{Araștırmanın Yöntembilimi}

Bu çalışmada içinde nitel araştırma türü seçilmiştir çünkü bir araştırma türü olarak, "nitel araştırma insanların yaşam tarzlarını, öykülerini, davranışlarını, örgütsel yapılar ve toplumsal değişimi anlamaya yönelik bilgi üretme süreçlerinden birisidir" (Özdemir, 2010, s.325). Dolayısıyla tarihsel gelişme içinde meydana gelen toplumsal değişimler paralelinde, reklamcılık alanında kadının toplumsal cinsiyet kimliğinde ortaya çıkan değişimleri incelemeyi amaçlayan bu araştırma nitel araştırma için uygunluk taşımaktadır. Araştırmamızda belirli bir konu (reklamların görsel tasarımında kadının değişen imgesi) seçilmiş ve bu konuyu açıklamak üzere belirli bir ürün grubu (kozmetik reklamları) incelenmiştir.

Toplumsal cinsiyet ile ilgili alandaki literatüre bir katkı sağlamayı amaçlayan bu araştırmanın amacı; kozmetik reklamlarında kadın temsilinin görsel ve maddi dönüşümü üzerine tarihsel bir bakış açısıyla feminist bir inceleme gerçekleştirmektir. Feminist araştırmayı "incelemenin merkezine toplumsal cinsiyetin toplumsal inşasını koymak" olarak gören Lather, bu tür araştırmaların temel amacını şu şekilde açıklamaktadır: "Feminist araştırmanın insan bilimleri içindeki ideolojik amacı, dişi tecrübenin görünmezliğini ve tahrifata uğramışığını, kadının eşit olmayan toplumsal konumunu sona erdirmeye uygun yöntemlerle düzeltmektir" (Lather, 1991, s.71). Feminist araştırmaları sosyal bilimler içindeki araştırmalar içinde özel bir yere koyan temel nitelikler ise şu şekilde saptanmaktadır: "1. Feminist bir bakış açısının kabulü ve toplumsal cinsiyet ilişkilerine odaklanmak, 2. Geleneksel bilimsel yöntemlerde vurgulananın aksine gündelik hayat ve kişisel deneyimlere verilen önem, 3. Araştırmacı ve araştırma arasındaki hiyerarşinin reddi, 4. Kadınların özgürleşimi ve toplumsal cinsiyet eşitsizliklerinin ortadan kaldırılmasının araştırma hedefleri arasında yer alması" (Öztan, 2016, s.277). Toplumsal cinsiyet olgusunu araştırmanın merkezine koyan ve toplumsal cinsiyetin toplumsal inşasında kapitalist sistem içindeki ataerkil ussallaştırmayı eleştiren feminist araştırmalar, aynı zamanda kadınların özgürleşme hareketlerinin sağladığı yeni toplumsal konumların yaygınlaştırılmasını ve teşvik edilmesini sağlama işlevine de sahiptir. 
Bu nedenle bu çalışmadaki temel vurgu, feminist bir amaç olarak kadının toplumsal yapı içinde güç kazanmasını sağlayan toplumsal değişimlerin sergilenmesine kuramsal düzeyde bir katkıda bulunulması üzerinde olacaktır. Bu amaçla, kadının toplumsal cinsiyet kimliğine yönelik mesajları belirli dönemler içinde belirli yönlerden en iyi şekilde veren kozmetik reklamları ele alınacaktır; bu reklamlar hem temel görsel imgeleri ve tasarımlarıyla hem de toplumsal referanslara sahip olan metinleriyle; söz konusu dönem içindeki kadın ile ilgili çalışmalarda ortaya konulan toplumsal cinsiyet ile ilgili kavramlar ve temalar bağlamında eleştirel bir tavırla ele alınacaktır.

Araştırmanın tarihsel bir boyut içermesi özellikle önem taşımaktadır. Çünkü tarihsel bir boyut taşıyan araştırmalarda, "tarihsel incelemenin odak noktası olarak beyaz erkeğin meselelerinin ve etkinliklerinin merkezden uzaklaştırılması ve cinsiyetin tarihsel çözümleme için temel bir kategori haline getirilmesi" ve feminist araştırmalara "cinsiyetin bir kategori olarak dahil edilmesi, tarihçilere tarihin her iki cinsiyet üzerindeki etkisine dair kompleks bir anlayış sağlayacaktır” (Hesse-Biber, 2012, s.7). Bu anlayış ataerkil zihniyetle oluşturulan erkek tarihinin yerine her iki cinsin meselelerini ve etkinliklerini eşit bir biçimde aktaran bir tarihsel bakış ortaya çıkaracaktır. Bu türden eşitlikçi ve nesnel bir tarihsel bakış, kadınların erkeklerin tarihi içinde edilgin konuma itilmesini engelleyecek ve kadınların tarihi oluşturmakta etkin özneler olarak kabul edilmesini mümkün kılacaktır. Kadını etkin bir biçimde tarihi oluşturan bir özne olarak ortaya koyan feminist araştırmalar, aynı zamanda kadın eşitliğine ve özgürleşimine katkıda bulunan kuramsal bir bilgi birikimi de oluşturmaktadır. Bu kuramsal bilgi birikimini oluşturan feminist araştırmalar "iktidar, otorite, etik ve düşünümsellik konularını toplumsal araştırma pratiği içine almanın önemini vurgulamaktadır" (HesseBiber, 2012, s.17). Feminist araştırmalarda bu şekilde vurgulanan "iktidar ve otorite" konuları çalışmamızın da kapsamı içinde yer almaktadır.

Bu bağlam içinde araştırmanın temel sorusu şu şekilde formüle edilebilir: "Tarihsel olarak kozmetik reklamlarının görsel-metinsel tasarımında kapitalist ataerkil ideoloji belirleyiciliğinde inşa edilen kadının toplumsal cinsiyet kimliği zaman içinde nasıl bir değişim göstermektedir?" İnceleme içinde temel araştırma sorunları ise, şu şekilde ifade edilebilir:

Araştırma Sorunu 1: Kapitalist ataerkil ideoloji, tüketim kültürü bağlamında kozmetik reklamlarında kadının toplumsal cinsiyeti ile nasıl bir ilişki içinde bulunmaktadır ve bu ilişki reklamların görsel tasarımında ve metninde nasıl yansıtılmaktadır?

Araştırma Sorunu 2: Kapitalist ataerkil ideolojiye muhalif kadın toplumsal cinsiyet temsillerini ortaya çıkaran toplumsal değişim koşullarına paralel bir biçimde gelişen birinci kuşak feminizm dönemi içinde, kozmetik reklamlarında kadının toplumsal cinsiyet temsili görsel tasarım açısından nasıl bir değişime uğramıştır?

Bu bağlamda feminizmin özgül bir alan olarak kozmetik reklamlarındaki etkisine ve kadının toplumsal cinsiyet temsillerinin görsel/metinsel tasarımı üzerindeki belirleyiciliğine bakılacaktır. Ardından toplumsal yapıdaki değişimlere paralel bir biçimde ortaya çıkan yeni ve muhalif kadın imgeleri ele alınacaktır. 
Araştırmada belirli tarihsel bir dönemleştirme içinde yayınlanmış olan basılı reklamlar veri kaynakları olarak kullanılacaktır. Bu dönemleştirmede, birinci kuşak feminist hareket temel alınacaktır. Genel kabul gören anlayış içinde, feminist hareket aşağıda gösterildiği şekilde dönemlere ayrılmaktadır (Dönemleştirme için bkz: Peake, 2017, s.85):

1. Birinci Dalga Feminizm (1800’lerin sonları - 1960'lar)

2. İkinci Dalga Feminizm (1960’lar - 1980'ler)

3. Üçüncü Dalga Feminizm (1990’lar - 2007)

\section{Dördüncü Dalga Feminizm (2007 - Sonrası)}

Araştırma içinde kullanılan kozmetik reklamları, literatür taramasıyla elde edilen ve ele alınan dönemi en yeterli ve başarılı şekilde yansıttığı ilgili literatür tarafından kabul gören basılı reklamlar arasından amaçlı örneklem yöntemiyle seçilmiştir. Reklamların seçiminde özellikle gözetilen husus; ilgili literatür içinde ele alınan meseleleri ve temaları görsel tasarımlarıyla olduğu kadar sözel öğeleriyle somutlaştırmaları ve yeni kadın imgelerini sunmaları olmuştur. Kozmetik reklamlarının amaca uygun seçilmesindeki temel ölçütler aşağıda olduğu gibi maddeler halinde sunulabilir:

(a) Seçilen kozmetik reklamlarının feminist literatür tarafından ortaya konulması ve teyit edilmesi.

(b) Seçilen kozmetik reklamlarının feminist literatür içinde tartışılan temel meseleleri ve temaları ele almaları,

(c) Seçilen kozmetik reklamlarının toplumsal cinsiyet konusunda meydana gelen toplumsal değişimi ifade eden nitelikte olmaları.

Bu çalışma metinsel düzeyde ve görsel tasarım açısından işaret edilen temel araştırma sorularını, amaçlı örneklem yöntemiyle seçilen kozmetik reklamlarını kullanarak ve kapitalist ataerkil ideolojinin imge ve kavramlar düzeyinde nasıl işlediğini ortaya çıkararak yanıtlamayı amaçlamaktadır. Çünkü reklamcılıkta iktidar ilişkileri sözlere olduğu kadar görsel tasarıma ve imgelere dayalı olarak da inşa edilmektedir. Kadına yönelik eşitsiz toplumsal konumların ataerkil inşa tarzına karşı feminist bir inceleme, kaçınılmaz bir biçimde ataerkil söylemlere karşı özgürleşimci bir tavır içinde eleştirel olmayı gerektirmektedir. Bu amaçla kozmetik reklamlarında kadın imgesinin tarihsel gelişimi doğrultusunda önem taşıyan meseleler eleştirel bir bakış açısıyla verilecek, bu meselelerin güncel bir değerlendirmeyle ortaya konulması sağlanacaktır. Bu incelemede feminist literatür içinde ortaya konulan kavram ve temalar çerçevesinde, birinci dalga feminist hareket içinde kadının toplumsal cinsiyet alanında elde ettiği kazanımlar verilecek ve bunların getirdiği yeni toplumsal cinsiyet konumlarını ifade eden kozmetik reklamları görsel tasarımları ve metinleriyle ele alınacaktır. 


\section{Kozmetik Reklamlarında Değișen Kadın Temsilleri}

Toplumsal yapıdaki toplumsal cinsiyete ilişkin değişimlerin kozmetik reklamlarında kendine özgü bir görsel tasarım ve metin yapısı ile yer bulduğunu rahatlıkla gözlemleyebilmek mümkündür. Bu anlamda, kozmetik reklamları kapitalist ataerkil ideoloji ile kadın hareketleri arasındaki mücadelenin simgesel düzeyde görselleştirildiği politik bir alan olarak da değerlendirilebilir. Kozmetik reklamları-parfüm gibi-elle tutulan somut bir ürün sunmamalarına rağmen, bu ürün için yaratılan güçlü toplumsal cinsiyet imgeleri görsel tasarım, sözel dil ve beden dili aracılığıyla güçlü bir etki yaratmaktadır. Bu nedenle kozmetik reklamlarının feminist bir okuması, bu reklamlardaki ideolojik alt metinlerin işleyişinin ortaya çıkarılmasını mümkün kılacaktır.

Bir konununaltınınözellikle çizilmesigerekmektedir; moda vekozmetikreklamlarındayer alan mesajlarda kadının kendini erkeğe beğendirme yönündeki davranışı ve düşüncesi, kapitalist ataerkil ideoloji ve toplumdaki eril beklentiler doğrultusunda oluşturulmaktadır. Ataerkil kapitalist sistemin üstü örtülü biçimde yürüttüğü bu dayatma politikası nedeniyle, kadınlar kendilerini erkeğe hem cinsel hem de güzel bir öğe olarak sunma fikrine alıştırılmaktadır. Bu nedenle hangi kuşak feminizm içinde yer alırlarsa alsınlar, feminist kuramcı ve yazarların karşı çıktığı temel düşünce, kadının reklamlarda gerçekçi bir biçimde yansıtılmayıp kapitalist ataerkil ideoloji doğrultusunda sunulmuş olmasıdır. Reklam ve kadın ilişkisi söz konusu olduğunda esas olarak şu eleştiri yapılmaktadır: "Modayla birlikte, yenilik, değişim ve ilerleme kavramlarını bir arada görmemiz mümkün olabilmektedir. Kadın tüketicilerin modaya ilgilerinde elbette reklamların rolü inkar edilemez. Yapılan reklamlarda kadının üç farklı amaçla kullanılığını görüyoruz. Bunlar, çalışan kadın imajı, ev kadını imajı ve seks objesi olarak kadın" (Sarıkaya, 2007, s.189). Genel olarak bütün reklamlar için geçerli olan bu eleştiri, moda ve kozmetik reklamları için daha fazla geçerlilik taşımaktadır. Çünkü kozmetik reklamları doğrudan kadın bedeni ile ilgili mesajlar vermekte ve kadın cinselliğini ve toplumsal cinsiyetini metaforik bir anlatımla vermektedir. Dolayısıyla kadın güzelliğinin şekillendirilmesinde en belirleyici araç olan kozmetik reklamlarında bu vurgu iyice artmaktadır.

Ancak bu türden bir değerlendirmenin, toplumsal yapıda meydana gelen değişimleri ve etkilerini saptama konusunda olumsuz bir etki yaratmaması gerekir. Çünkü modern toplumlarda toplumsal değişim son derece hızlı meydana gelmekte ve toplumsal tarihi toplumsal değişim dönemleri bağlamında takip etmek neredeyse bir zorunluluk haline gelmektedir. Toplumsal değişimlerin en iyi takip edilebildikleri alanlardan biri reklamlardır: "Reklamcılık, toplumsal değişime aracılık eden -ve böylesi bir değişimin içinde tanık olunabileceği- bir iletişim etkinliğidir. Bu, reklamcılığın tüketim toplumunda merkezi belirleyici bir etken olduğunu söylemek değildir; burada daha çok, reklamcılığı karmaşık tarihsel gelişmeleri anlama konusunda vazgeçilmez bir yorumlayıcı anahtar olarak sunmaktayı" (leiss, Kline ve Jhally, 1997, s. 193). Bu nedenledir ki, reklamverenlerin ve reklamcıların toplumsal yapıdaki değişimleri kavramaları ve bu değişime uygun tarzda yeni rol modeli olacak kişilik sunumlarını reklamlarında yansıtmaları söz konusu olmaktadır. 
Tarihsel gelişim çizgisinin tanıklıkettiği üzere, kozmetik reklamları da kadın hareketlerinin mücadelesinin sonucunda ortaya çıkan toplumsal değişimlere paralel bir biçimde değişen kadın temsillerini yansıtmaktadır. Kozmetik reklamlarında feminist hareketin her dönemine göre ortaya çıkan kadın temsillerinin üretilmesi, hem bir toplumsal talebe yanıt vermekte hem de toplumsal altyapıda meydana gelen değişimleri karşılamak üzere döneme uygun kişiliklerin topluma tanıtımasını ve zihinlere yerleştirilmesini amaçlamaktadır. Çünkü genel olarak reklamlarda özel olarak kozmetik reklamlarında, kültürel ve estetik açıdan döneme uygunluk sağlayacak bir görsel tasarım aracılığıyla dönem içinde talep edilen türden kişilikler yansıtılmaktadır:

"Ekonomik ve toplumsal yapıda ortaya çıkan her köklü değişim kişilik değişimine de yol açar. Bu tür kişilik değişimleri, sık göründükleri yerlerde, sözgelimi belli toplumsal katmanlarda, meslek ve yaş gruplarında, alt kültürlerde, yaşam dünyalarında ya da belli sosyal ortamlarda özellikle dikkat çeker. Söz konusu insanların düşünme, hissetme ve eylemde bulunma davranışını önemli ölçüde etkileyen bir kişilik tipi tam da buralarda oluşur. Ama bu yeni kişilik tipi sadece geniş ölçüde davranışı belirlemekle kalmaz, aynı zamanda insanların kendileri, kendi imkanları ve sınırları, başkaları, ortam ve gelecek hakkında geliştirdikleri değerleri ve tasavvurları da beraberinde getirir, işte bu yeni kişilik tipini başka yerleşik tiplerden ayıran da bu değerler ve tasavvurlardır. Yeni bir kişilik tipi gitgide yaygınlaşıyorsa, bu onun kışkırtıcı bir çekiciliğe sahip olduğu anlamına gelir, işte bu tip insanların somut düzeydeki ayırıcı özelliği bu kışkırtıcı çekiciliktir" (Funk, 2013, s.11).

Toplumsal gerçeklik içinde ortaya çıkan dönemin kişilik tipleri her türlü kültürel üretim alanında - sanat, reklamcılık, politika, vb- karşılığını bulmaktadır. Kozmetik reklamları da "koku ile (kokunun şehvet ve cinsellikteki rolünü ima eden) insan duyuları arasındaki ilişkiyi ve bir kimliğin (toplumsal beden) bedene giydirilmesini vurgulayarak, her bir parfümle bağlantılandırılmış nitelikler ve rol modelleri oluşturmaktadır" (Craik, 1993, s. 159). Böylelikle diğer kültürel alanlarda olduğu gibi kozmetik reklamlarında da yeni bir dönemin yeni bir kadın kişilik tipinin temsilini bulmak ve tarihsel bir değerlendirme içinde kadın imgesinin evrimini takip edebilmek mümkün olmaktadır.

Sosyolojik olarak bir olgunun gelişimini farklı sistematik ölçütler içinde takip etmek mümkün olduğu gibi, bir olguyu belirgin nitelikleriyle ortaya konulabilecek dönemleştirmeler içinde incelemek de mümkündür. Kültür ile ilgili alanlara tarihsel boyutta yaklaşan çalışmalarda, seçilen dönemleştirme kuramcıların gerçekleştirdikleri çalışmalarını gruplar içinde ele almalarında ya da tarihsel geçmişe sahip olguları belirli temalar etrafında sınıflandırmalarında işe yaramaktadır.

Bu sosyolojik çerçeve içinde toplumsal hareketlerin dönemleştirilmeleri de, yarattığı politik kültür nedeniyle işlevsel bir inceleme alanı sağlamaktadır. Bu nedenle feminist kuramda kabul gördüğü şekliyle feminizmin tarihsel dönemleri içinde bir inceleme yapılması verimli bir çalışma alanı ortaya çıkarmaktadır. Her feminist kuşak kendi tarihsel dönemi içindeki kavram ve temalarla ilişkili biçimde ele alınabileceği gibi, bir kuşağın kendinden önceki ve sonraki kuşaklarla etkileşimleri içinde değerlendirilebilmesi 
de mümkündür. Bu bakımdan her feminist kuşağı kendilerinden önceki kuşağın ardıl ilişkileri bağlamında değerlendirmek ve bu ilişkilerin kozmetik reklamlarındaki yansımasını ortaya koymak da yarar sağlayacaktır.

\section{Birinci Kușak Feminizm ve Kozmetik Reklamları: Eșitlik ve Özgürlük Talebi}

Birinci kuşak feminizmin temel tema ve konularını (eşit haklar, kadının çalışma koşulları, oy verme hakkı, cinsel ve ekonomik yönden özgürleşme talepleri, vb) özellikle moda ve kozmetik reklamlarında gözlemleyebilmek ve dönemin kadınlarının özgürleşim çabalarının karşılığını bu reklamlarda saptayabilmek mümkündür. Bu durumun nedeni, 1900'lü yılların başlarında gelişen moda endüstrisiyle birlikte, moda ve kozmetik ürünlerinin -özellikle parfümlerin- kadının yaşamı içindeki yeri önem kazanmasıdır. "Yüzyıl açılırken, mükemmel bir parfüm, iyi giyinmiş Parisli bir kadın için en son elbise modası kadar elzemdi. Fransız parfüm endüstrisi ise gelişmekteydi" (McAuliffe, 2014, s.10). Böylece günümüzdeki anlamıyla hızla gelişmekte olan moda ve kozmetik sektörleri birbirini destekleyen bir biçimde paralel bir gelişim çizgisi içine girmişti.

Birinci kuşak feminizm içinde toplumsal cinsiyet anlayışında ortaya çıkan dönüşümleri ekonomik ve toplumsal altyapıda meydana gelen değişimlerin ortaya çıkardığı koşullar bağlamında ele alacak olursak, bu dönemde moda ve kozmetik reklamları modern kadının yaratılmasında ve toplumsal yaşama girmesinin sağlanmasında işlev gördüler. "Reklamcılıkta kadınlar moderniteye uyum sağlarken iki şekilde tasvir edildiler: malları satın alma güçleriyle ve bedenlerini biçimlendirme ve giydirme biçimleriyle" (Murray, 2017, s.72). Böylelikle kadınlar da gelişmekte olan tüketim kültürü içinde öncelikle bir tüketici olarak dikkat çektiler ama bu yeni konumları geleneksel konumlarının iyileştirilmesi yönünde fazla olumlu etkide bulunmadı.

İlk kozmetik reklamlarında kadınlar ağırlıklı olarak geleneksel rolleri ve işlevleri içinde yansıtıldılar. Bu dönemdeki parfüm reklamları, geleneksel tavır doğrultusunda kadınları çiçeksi kokulara uygun bir simgesellik içinde sunan görsel tasarımlar kullanmaktaydılar. Bu nedenle altmışlı yıllara dek sürecek bir anlayışla, kadınlar çoğunlukla çiçeksi kokularıyla erkeği etkileyerek kadınsı güçlerini gösteren bir şekilde kozmetik reklamlarında yer aldılar. Ayrıca bu dönem kozmetik reklamlarında yer alan kadınların -tüketici konumlarına paralel bir şekilde- belirleyici olarak beyaz, orta sınıf, heteroseksüel ve geleneksel konumlarını benimsemiş kadınlardan oluştuğunu; bu reklamlarda ırksal ve etnik azınlıklara ait kadınların fazla tasvir edilmediğini belirtmek gerekir.

Bu nedenledir ki, kozmetik reklamları gibi doğrudan toplumsal cinsiyet kimliğine yönelik reklamlarda yapılan araştırma ve incelemeler daha dikkat çekici bir önem taşımaktadır. Çünkü kozmetik reklamları kadının toplumsal cinsiyet kimliğinin oluşturulması açısından diğer ürün kategorilerine oranla daha güçlü mesajlar vermekte ve daha fazla toplumsal yönlendirme gücü taşımaktadır. Bu gücün kaynağında kozmetik reklamlarının ağırlıklı olarak kadınlara yönelik hazırlanmaları; kadınlara bir kadın olarak tanımlanmak 
için nasıl bir görünüm edinmeleri ve nasıl davranmaları gerektiğini söylemeleri ve kadınlara nasıl bir sosyal statüye sahip olabilecekleri konusunda yönlendirmelerde bulunmaları yatmaktadır. Bu bakış açısından yaklaşıldığında şunu rahatlıkla ileri sürmek mümkündür ki; "kadının toplumsal tarihi giysiler, kozmetik ve materyal kültür içine nakşolmuştur" (Dyhouse, 2013, s.7). Bu bakımdan sözden/yazıdan çok, ağırlıklı olarak görsel tasarıma dayalı biçimde hazırlanan kozmetik reklamlarında, hem reklamın hem de kadının görsel tasarımı ön plana çıkarılmaktadır. Böylelikle kozmetik reklamları kadınlara toplumsal cinsiyet kimliklerini ifade etmek için yüzlerini ve bedenlerini kültürel bir dışavurum alanı olarak nasıl bir görsel tasarım içinde biçimlendirecekleri konusunda da açık ya da örtük mesajlar vermektedir.

Yüzyıl başında reklamcılığa yönelik feminist bir etkiyi yönlendiren ilk kadın hareketi "suffrage" olmuştur. Kadının erkek ile eşitliği, oy hakkı, politik ve ekonomik özgürlüğü gibi temel haklar çerçevesinde hareket içinde yer alan kadınların medya içindeki olumsuz temsilleri hususunda duyarlılığa sahip olan bu hareketin mensupları, "tüketicilerin kişisel kimliklerini ifade etmek için kullandıkları şekilde, modayı politik aktivizm ile bağlantılı bir kamusal kimlik yaratmak ve yönetmek için kullandılar" (Murray, 2017, s.64). Bu dönem içinde kadınsı ve erdemli olarak kabul edilen modern kadın kimliğinin bu etkiyi yansıtacak bir moda tarzına uygun şekilde temsil edilmesi, yüzyıl başındaki kadınların değişen döneme uygun bir tarzda çekicilik taşıyan bir kimlikle ortaya çıkmalarına olanak tanımıştı.

Bu dönemin başlarında Birinci Dünya Savaşı'nda erkeklerin askere gitmesi nedeniyle onların boşaltığı işlerde çalışmaya başlayan ve bu nedenle toplumsal yaşama daha çok katılan ve kamusal alanda daha fazla yer alan kadınlar ortaya çıktılar. Değişen toplumsal koşulların ve gelmekte olan yeni dönemin görsel tasvirleri olarak değerlendirilebilecek olan ve "flapper" olarak da adlandırılan bu kadınlar, bir anlamda dönemin ilk kuşak feminist kadınlarının da görsel tasarım aracılığıyla dışavurumunu sağlamışlardır. Yirmili yıllarda Amerika'da ortaya çıkan ve daha erkeksi bir görünüme sahip, kısa etekler giyen, enselerini açıkta bırakacak şekilde saçlarını kısa kestiren, içki ve sigara içen, "gizemli kadın çekiciliği" düşüncesinden sıkılan ve daha özgür bir imaj sahibi olan bu tür kızlara hitap edecek bir giyim tarzı da moda olmuştu. Kadınlara oy verme hakkını tanıyan yasaların geçmesini sağlayan kadın hareketlerinin sonrasında, elde ettikleri kazanımlarla erkeklerle eşit haklar talep eden bu kadınlar, üzerlerindeki ataerkil toplumsal baskıyı reddederek toplumsal yaşamda daha etkin bir konumda yer aldılar (Gourley, 2008, s.60-66).

Dönemin modasına uygun biçimde kozmetik endüstrisi de doğal olarak yeni kadına hitap edecek kadın temsillerini reklamlarda kullanma çabasına girişti. "Neşeli, kendine düşkün, cinselliğinin farkında olan ve maceracı bu 'yeni kadın'ın flapper imajı aynı zamanda sigara, parfüm, çikolata, araba ve diğer lüks ürünlerin reklamcılarının işine gelmişti... Genişleyen kozmetik ve güzellik ürünleri... sahasındaki reklamcılar için flapper ideal bir ikon olmuştu" (Macdonald, 2004, s.50). Bu nedenle bu yeni kadın tipi hem tüketici hem de reklam imgesi olarak kısa zamanda reklamcılık sektörü içinde yer almıştı. Ayrıca bu yeni tüketici ve reklam imgesi olan "flapper kadını" sadece Amerika 
ile sınırlı bir varoluş alanına sahip değildi. Bu dönemde The New Yorker dergisine katılan ve Fransa'ya giden Lois Long "Amerikan flapper'inin izole bir olgu olmadığını görmüştü. Giysi ve kozmetikler kitlesel düzeyde pazarlanırken, farklı bölgelere ve sınıflara ait insanlar arasındaki çizgiler de aniden bulanıklaşmıştı. Flapper rolü, her genç kadının oynayabileceği bir roldü” (Zeitz, 2006, s.123). Böylelikle reklamcılık açısından modern kadının rolü bu iki yönüyle belirlenmiş oluyordu: Öncelikle kadınlar artık satın alma güçleriyle pazar içinde yer alarak reklamçların dikkatini çekebiliyorlardı. İkinci olarak ise, giysisi ve kozmetiğiyle birlikte kendisini yeni döneme uygun bir görsel tasarım içinde sunabilen kadın imgeleri sonraki dönemler içinde de değişen toplumsal değerlere göre kozmetik reklamlarında yer aldılar.

Bu tür reklamların ilklerinden biri Tabac Blond parfümüydü. Kozmetik ürünlerin yalnızca kullandıkları toplumsal cinsiyet imgeleriyle değil, aynı zamanda dönemin ruhunu yansıtan adlandırmalarla da sosyolojik imalar taşımasına uygun bir biçimde, 1919 yılında piyasaya çıkan Tabac Blond parfümü "sigara içen kadınlara övgü olmuştu. İlk çıktığında, bu kadınlar çok 'modern'diler ve bu parfüm açıkça bu geleneksel olmayan kadınları cezbetmeye niyetliydi” (Rhind, 2014, s.278). Böylece tütünün kokusunu ve dönem içindeki anlamını adına taşıyan Tabac Blond, erkeklere özgü deri kokusu ile çiçeksi kadın kokularını harmanlayarak erkek gibi sigara içip özgürlüklerini göstermek isteyen kadınların simgesi olmuştu. Ürünün reklamında, sanat tarihi içinde yer alan tablolarda kendisini aynada seyreden Venüs imgesine göndermede bulunularak kadınsılık vurgulanırken, aynanın önündeki sigara ile modern kadının erkeksi tavrı ve özgürleşim arzusu ima edilmekteydi. Tabac Blond, dönemin film starı Marlene Dietrich tarafından da kullanılan ve bu nedenle sigara içerek bağımsızlıklarını göstermek isteyen kadınların özgürleşme arzularının bir göstergesi haline gelmişti. Dietrich'in gösterdiği bu etki kendisiyle sınırlı değildi; reklamcılık endüstrisi ile sinema endüstrisi arasında bu yıllarda ortaya çıkan ilişki içinde, birçok film yıldızı kadınların bedenlerini şekillendirmek için kullanılan giysiler ve farklı kozmetik ürünleri için reklam yüzleri olmuşlardı. “Doğrudan ya da dolaylı bir biçimde, 1910'larda ve 1920'lerde ortaya çıkan beden şekillendirme ürünleri ve yöntemleri çekiciliklerini Hollywood tarafından kurulan standartlar üzerine kurmuşlardı. Beden şekillendirme ürünleri ile ilgili reklamlar diğer popüler dergilerden çok film dergilerinde daha sık görünüyorlardı" (Addison, 2000, s.10). Bu etkileşim içinde modacılar ve kozmetik üreticileri. ürünlerini onaylatan ve tanıtan reklamlarda film yıldızlarını kullandılar. 


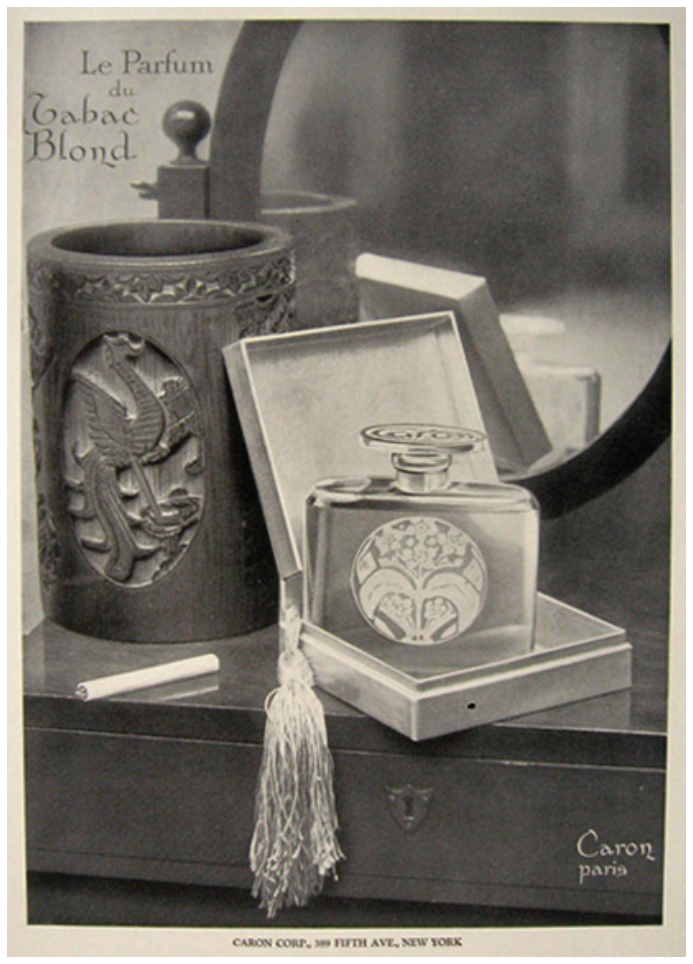

Resim-1: Tabac Blond Parfümü Reklamı (1920'ler)

Birinci Dünya Savaşı sonrasındaki toplumsal değişime ve yeni dönemin kadınına hitap eden parfümlerin genel niteliği şu şekilde saptanabilir: "1920lerin kadın parfümleri, şüpheli bir ahlaka sahip, sigara içen kadınları çağrıştıran tütün notalarının eşlik ettiği çiçeksi notaların Eros'una, hayvani kaynaklı notaların Thanatos'u ile birlikte katılılar. Sözün kısası, kadınlığı masum çiçeksiliğin dışında yeniden tanımladılar. Bu dönem, Lanvin'in My Sin'in, Molinard'ın başlangıçta sigaraları parfümlemek için yapılmış olan Habanita'sının ve kadınların gül gibi değil 'kadın gibi' kokmaları için yaratılmış olan çığır açıcı Chanel No.5'in on yılıydı" (Herman, 2013, s.31). Dönemin yeni kadının cinselliğini geleneksel çiçeksi kokuların dışında erkeksi tütün notaları ile birleştiren ve reklam imgelerinde daha özgür bir cinselliğe işaret eden bu parfümler, kadın hareketlerinin ilk döneminin sağladığı özgürlük ortamının ortaya çıkardığı yeni modern kadın kimliğine hitap etmekteydi.

Çiçeksi kokulara sahip sevimli kadınlardan kopuşun gerçekleşmeye başladığı ve daha etkin rollere sahip yeni kadın karakterlerin belirmeye başladığı yirmili yıllardaki talebe yanıt veren en simgesel kokularından bir diğeri Coco Chanel'in Chanel No.5 parfümü olmuştu. "Coco Chanel kadının toplum içindeki geleneksel rolünün sonunu işaret etmekteydi. Coco Chanel erkeksi görünümü empoze eden ilk tasarımcı olmuştu” (Landers, 1992, s.262). Parfümün Georges Goursat tarafından çizilen illüstrasyonunun 
yer aldığı reklam görselinde dönemin flapper kadının bir temsilini görmek mümkündü. Chanel No.5'in değişen dönemlerde değişen toplumsal koşullara eşlik eden kadın imgelerini sonraki yıllarda da görmek mümkün olacaktı.

Bu dönemin reklamlarının görsel tasarımında egemenlik süren flapper kadın imgesi, bir yandan dönemin kadınlarının özgürleşim arzularını ve eylemlerini yansıtan bir figür haline gelirken, diğer yandan kadını her zaman diyet yapmaya yönlendiren ince beden zorlaması nedeniyle eleştiri konusu olmuştur. Özellikle moda ve kozmetik reklamları aracılığıyla kadın bedeninin cinsel bir nesne haline getirilmesi suçlaması, günümüzde de kadının cinsel özgürlüğü temasının tüketim kültürü içinde sömürülmesi ile ilgili eleştirileri arttırmıştır.

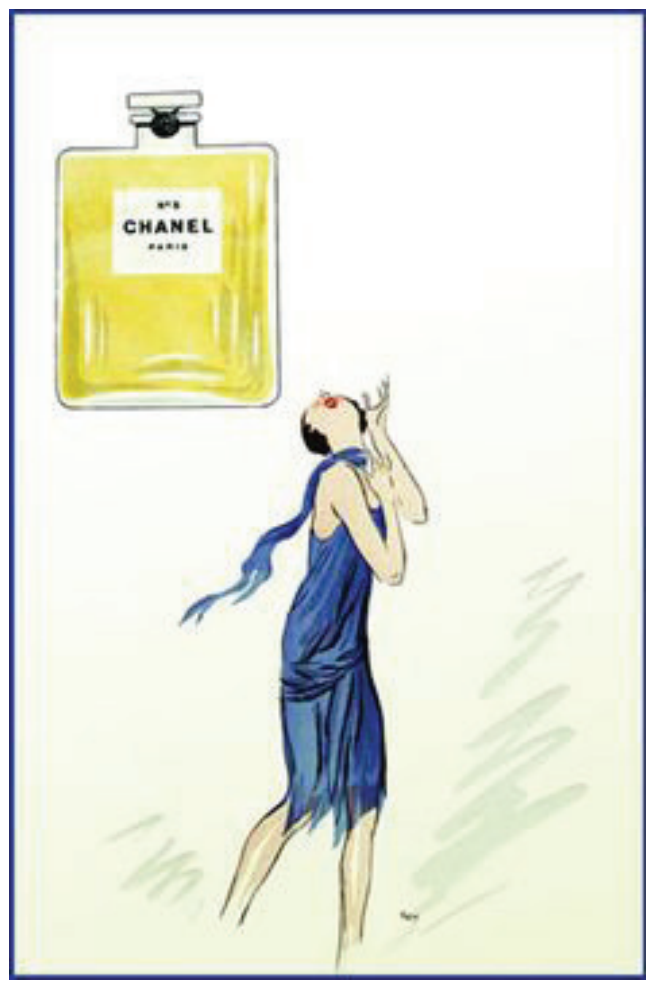

Resim-2: Chanel No.5 Reklamı (1921)

Yirmili yılların özellikle cinsellik yönünden daha modern ve özgür kadın imgeleri, reklamlarda değişen toplumsal koşullara uygunluk gösterecek görsel tasarımların ve kadın imgelerinin ortaya çıkmasına olanak tanıyarak kültürel bellek içinde yer almasını sağlamıştı. Bu imgelerin yaygınlaştırılmasında ise en büyük paylardan biri reklamcılık sektörüne aitti. "Reklamcılık 1920'lerde ve 1930'larda Modern Genç Kadın tarzının eşzamanlı biçimde dünyada ortaya çıkmasının temel araçlarından birisi olmuştu... Kozmetik reklamları Modern Genç Kadınları yeni toplumsal durumlar içine 
-kamusal alanda romantizm yaşarken, spor yaparken, film yıldızı gibi poz verirken ya da banyoda kendine bakım yaparken- yerleştirdiler" (Weinbaum ve diğerleri, 2008, s.25). Bu bakımdan yirmili ve otuzlu yıllarda bu dönemin sosyo-ekonomik-kültürel dışavurumunu sağlayacak kadın imgeleri, en etkili ve çekicilik yaratan araçlardan biri olarak kozmetik reklamlarında sunuldu. Reklamcılar bu yeni kadını sunarken görsel teknikleri de ustaca kullandılar: "Modern Genç Kadın imgesinin tasarımcıları, mevcut en gelişmiş görsel teknolojiden yararlandılar.

Amerika'da, Çin'de, Almanya'da ve Hindistan'da, Modern Genç Kadın reklamları 1920 'lerde çizimlerden litografik suluboyalara ve 1920'li yılların sonlarında fotoğraflara (çoğu zaman film yıldızlarını, ünlü sanatçıları kullanarak) doğru değişim gösterdi” (Weinbaum ve diğerleri, 2008, s.32). Film yıldızlarının ve sanatçıların kozmetik reklamlarında kullanılması, dönemin simgeleri haline gelmelerini sağladığı gibi, diğer genç kadınların da modern bir genç kadın olmak için nasıl bir görsel tasarım içinde görünmeleri gerektiği konusunda güçlü imgelerin ortaya çıkmasını sağladı.

Otuzlu yıllara gelindiğinde ise, Büyük Bunalım'ın yaratmış olduğu sosyo-ekonomik ve kültürel ortamın etkisiyle kozmetik reklamlarındaki kadınların imgesi de değişime uğramıştı. "1930’larda Amerikan kadınının arzulanın imgesi, döneme hâkim olan ekonomik sıkıntıya tepki olarak daha olgun ve görgülü hale gelmişti. İdeal beden tipi, yirmili yılların genç flapper'inden daha olgun ve uzun bacaklı güzel kadına evrilmişti. Kırklı yıllarda ise, giderek daha fazla kabul gören çekici kadın imgesini yansıtan kışkırtıcı parfümler piyasaya çıktı" (DeLong ve Bye, 1990, s.82).

Bu yılların kozmetik reklamlarındaki kadın imgeleri - hedef kitlelerine göre olduğu kadar - dönemin kadın hareketlerinin etkisine ve muhafazakâr tepkinin artıp azalmasına göre, özgürleşim figürü olarak sunulan kadın imgelerinden geleneksel değerlere hitap eden kadın imgelerine gidiş gelişler içinde sunulan reklam imgelerini sergilemişlerdi.

1930'lu yıllardan başlayarak 1940'lı yıllarda da devam eden bu durumu en iyi gösteren reklamlardan biri Dana parfümünün 1932 yılına tarihlenen reklamıdır. Bu kozmetik reklamı, modern bir genç kadını romantik bir partner olarak yeni beden tasarımı içinde, dönemin sinema yıldızlarının fotoğraflarında olduğu gibi büyüleyici ve gösterişli bir güzellikle gösteren bir mizanseni kullanmaktadır. Bir film karesi gibi olan bu reklam, dönemin sinema filmlerinin ve fotoğraflarının görsel tasarımını kullanmaktadır. Gizemli ve romantik bir hava yaratan bu reklamda, sevgili ile romantik bir ilişki içinde tasvir edilen kadın, Dana'nın bir başka görselinde piyano çalarken kemancı erkekle öpüşen bir kadını gösteren fotoğrafa bakmaktadır. Reklamdaki kısa metinde "bu gece çok özel olabilir" denilirken, reklamın sloganında güçıü bir cinsellik imasında bulunulmaktadır.

Kutsal metinlerde yer alan öykü hatırlatılarak, Adem ve Havva arasındaki ilk günah akla getirilecek şekilde, cennette yenilen elmaya gönderme yapılmaktadır. "Dana'nın 'yasak' parfümü” ifadesi, yasak meyveyi ve dolayısıyla yasak eylemi çağrıştırmaktadır. Yasak sözcüğünün tırnak içine alınmasıyla ilk günah ve cinsellik vurgusu artııılmaktadır. 


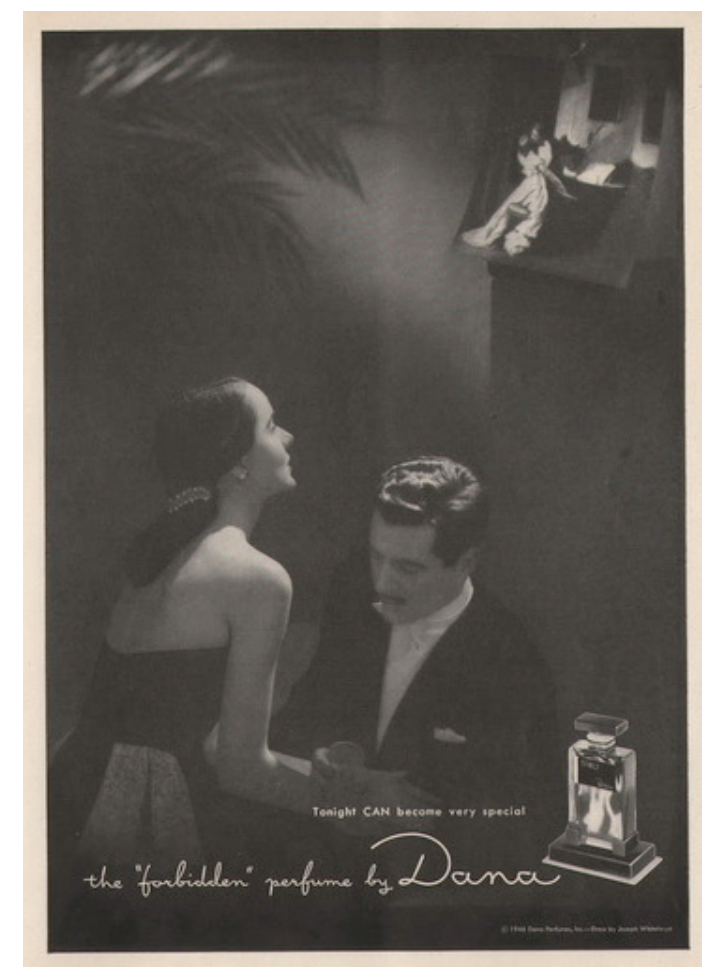

Resim-3: Dana Parfüm Reklamı (1932)

1940’lı yıllar ise kadın tarihinde 1. Dünya Savaşı'nın etkisine benzer şekilde sonuçlar ortaya çıkarmıştı. İkinci Dünya Savaşı sırasında da erkekler savaşa gittiğinde, kadınlar onların işlerini üstlenmek ve kamusal alanda olduğu kadar iş yaşantısı içinde de daha fazla yer almak durumunda kalmışlardı. Kadınların yeni toplumsal konumu, kitle iletişim araçlarında ve üretilen reklamlardaki görsel tasarımlarda karşıı̆ını bulmuştu. Kozmetik firması Avon'un 1945 yılındaki "Heroines" (Kadın Kahramanlar) başlıklı reklam kampanyası içinde yer alan reklamın görsel tasarımında "Her Courage Lives Today" (Onun Cesareti Bugün de Yaşıyor) başlığının altında Amerikan tarihinde savaşa katılan ve savaşta yaralanan bir kadın kahraman olan Deborah Sampson Garnet'in kısa öyküsü bir görsel ile verilmekte ve 1940'lı yılların kadın askeri aracılığıyla kadının cesareti ve başarma gücü ile bağlantı kurulmaktadır. Reklamda yer alan metinde doğrudan feminist temalar yansıtılmamakta ve ağırlıklı olarak dönemin milliyetçi duygularına ve askeri politikalarına uygunluk sağlanmaktadır. Bununla birlikte bu reklam, aynı zamanda yirmili yıllardaki kozmetik reklamlarında görülen modern kadınların döneme uygun bir versiyonunu sunmaktadır. Bu dönemin modern kadınını belirten sözler şu şekildedir: "Onlar kadın oldukları için samimiyetle karşılandılar ve böylelikle yüklendikleri her işe cesaret ve yeterlilik kadar canayakınlık ve nezaket kattılar." Avon'un bu dönemin kadınına sağladığı katkı şöyle verilmektedir. "Avon'un vatanseverlik açısından üstlendiği şey ise bu yeni canayakınlığın, çekiciliğinizi 
tamamlayan bir parçanız haline gelen bir canayakınlığın yolunu açmaktır." Dolayısıyla Avon kozmetik firması dönemin vatanseverlik duygularıyla harmanlanmış bir reklam mesajında, meşguliyet içinde bulunan kadınlara ürünlerini kendi satış temsilcileriyle telaşsız ve zevkli bir biçimde ulaştırmayı üstlendiğini belirtmektedir. Bu kozmetik reklamı, geleneksel tonlarına rağmen, bu dönemin kadınının bulunduğu yeri göstermesi açısından tarihsel belleğe yerleşecek bir görsel reklam tasarımı üretmiş olmaktadır.

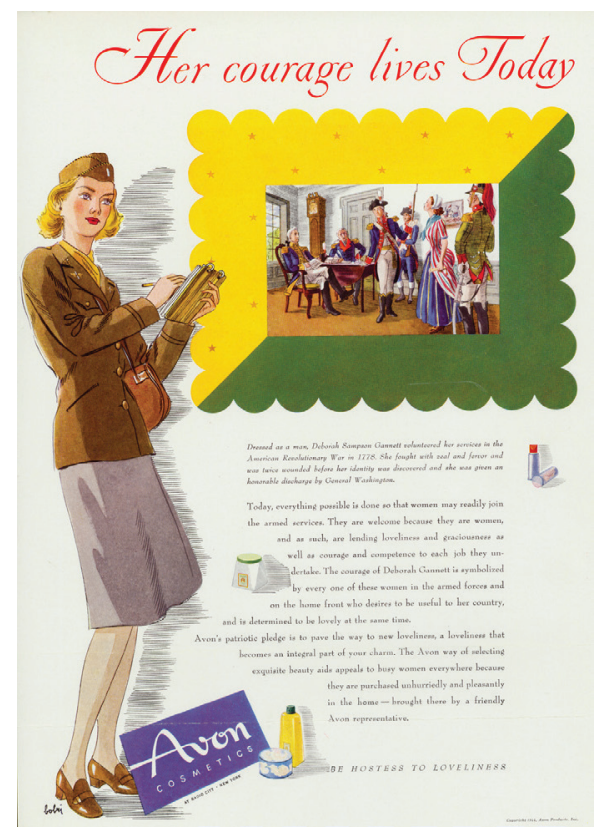

Resim-4: Avon Reklamı (1945)

Ellili yıllara gelindiğinde ise, kadının kamusal alandaki yerinin azalması ve toplumsal konumunda bir kayıp yaşaması söz konusu olmuştu. Toplumsal koşullardaki değişimi Amerikan toplumu üzerinden değerlendirecek olursak, "1950'ler Amerikan kadını için önemli bir dönem olmuştu. İkinci Dünya Savaşının sonu ile birlikte, erkekler Amerika'ya ve geçici olarak kadınlar tarafından üstlenilen işlerine dönmüşlerdi. İşlerinden çıkan kadınlar artık eve ve ev işlerine dönmüşlerdi” (Catalano, 2002, s.45). Kadının geleneksel rollerinin ötesinde elde ettikleri yeni kazanımlarını kaybetmeleri sonucuna yol açan bu toplumsal gelişme, yansımasını genel olarak reklamlarda özel olarak ise moda ve kozmetik reklamlarında gösterdi. "1950'lerde kadınsılık, zarafet ve cazibe parfüm reklamlarının temalarıydı... Bu formdaki reklamlar günümüzde de devam etmektedir" (Classen, Howes ve Synnott, 2003, s.189). Toplumsal değişimi yansıtan görsel belgeler olarak ellili yıllardaki parfüm reklamları; erkeği uyaran, onun kendisini erkek gibi hissetmesini sağlayan ve çekiciliklerini ortaya koyan bir imaj çizen kadınlardan oluşmaya başladı. Bu nedenle ayartıcı kadın ile saf ve masum kadın arasında giden kadın temsilleri bağlamında, kadını baştan çıkarıcı olarak gösteren reklamlarda dahi muhafazakârlık dozajı artmıştı: Kadının kendisini kocasına çekici göstermeye çalıştığı ve annelik rolü içinde gösterildiği temsiller göze çarpan hale gelmişti. 
Ellili yılların kozmetik reklamlarında kadınlar, ağır kozmetik kullanımına yönlendirilmekte ve doğal görünümlerinden uzaklaşmalarına neden olan aşırı kadınsı bir görünüme özendirilmekteydi. Altmışlı yıllarda ortaya çıkacak olan ikinci kuşak feminizmin kadınların pasif gösterilmelerinin ve cinsel yönden bastırılmalarının bir göstergesi olarak gördükleri için karşı çıktıkları bu kozmetik ürünleri ve reklamları, ellili yılların kozmetik reklamlarındaki kadın temsilleri üzerinde belirleyici oldular.

Aktarmış olduğumuz bu türden belirleyici reklamların görsel tasarımları ve sundukları kadın imgeleri sadece evsel alana geri döndürülmüş olan kadınlar için değil, aynı zamanda çalışmakta olan ve geleneksel rollerini yerine getirme yükümlülüğü taşıyan kadınlar için de geçerlilik taşımaktaydı. Max Factor kozmetik firmasının 1959 tarihli reklamının görsel tasarımı bu türden bir kadın imgesini içermektedir. "Günde 12'den fazla insanla karşılaşan kadın için makyaj mükemmelliği” sloganının yer aldığı reklamın görsel tasarımında, bir kadının evde, işte, toplumsal yaşamda ve alışverişte karşılaşabileceği insanlar verilmekte ve en önde mükemmel makyajı ve giysileriyle söz konusu kadın yer almaktadır. Sadece görselliği ile değerlendirildiğinde bile, sunulan "süper anne/kadın" imgesinin feminist kuramcılar tarafından neden eleştirildiği ortaya çıkmaktadır. Tüketim kültürünün kadın temsilleri üzerindeki olumsuz etkisini göstermesi nedeniyle feminist eleştirmenler tarafından ağır biçimde eleştirilen bir kadın imgesini sunmakla birlikte, bu reklam en azından çalışan kadın imgesini sunmasıyla dikkat çekmektedir. Bu anlamda bu reklamın ellili yıllarda kadınların kamusal alanda ve iş yaşantısında kaybettikleri cephenin etkilerini azaltan bir anlama sahip olduğu gözlemlenebilmektedir.

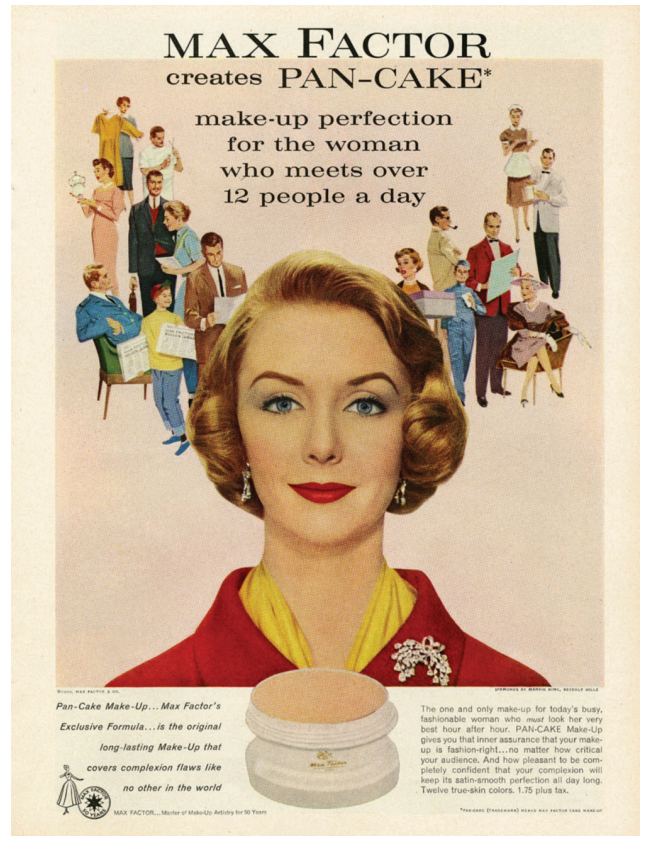

Resim-5: Max Factor Reklamı (1959) 
Ele almış olduğumuz tarihsel gelişmelerin ve reklam örneklerinin göstermiş olduğu üzere, ilk kuşak feminist hareketin etkisiyle sosyo-ekonomik ve kültürel alanda meydana gelen toplumsal değişimlerin neden olduğu koşullar bağlamında, kozmetik reklamları modern ve cinsel yönden olduğu kadar toplumsal koşullar açısından da daha özgür yeni kadın imgeleri ortaya çıkarmıştı. Ancak bunlar geleneksel kadın imgelerinin yanında nispeten daha az yer kaplamaktaydılar. Kitle iletişim araçlarının gelişen etkisiyle ve uluslararası markaların reklamlarının yaygınlaşmasıyla birlikte, farklı ülkelerde de benzer kadın imgeleri kozmetik reklamlarının görsel tasarımları içinde yer aldılar. Toplumsal cinsiyet anlayışında meydana gelen dönüşüme paralel biçimde, reklamlardaki görsel tasarım ve kozmetik reklamlarındaki kadın imgesi konusunda dönemin Meksika reklamcılığı üzerinden benzer saptamaları yapmak mümkündür: “Kozmetik reklamcılığı 1930’lardan 1950’ye kadar kadın güzelliğinin saf ve ayartıcı formaları arasındaki karşılıklı etkileşimi tasvir etti... 1930'larda, doğallığa vurguyu tamamlayacak şekilde saf ve masum güzellik reklamcılığı cezbetti... Kozmetik reklamcılığı 1940’lı yıllar boyunca da saflık duygusundan vazgeçmeden ayartıcı güzelliği vurguladı" (Moreno, 2003, s.145). Bu ikili vurgu aslında günümüz reklamcılığına kadar uzanan bir görsel tasarım anlayışını ve kadın temsillerini içermektedir. Kozmetik ürününe ve hedef kitleye göre tasarlanmış kozmetik reklamları, aynı ikiliği hala reklamların görsel tasarımında kullanmaktadır. Bu ikili kullanım, değişen tarihsel dönemlere ve kozmetik reklamlarının yer aldığı toplumlara göre ayarlanmış bir dozaj içinde günümüz kozmetik reklamlarında da görülmektedir.

Yukarıdaki reklam örneklerinin göstermiş olduğu gibi, tüketim toplumu içinde kadının toplumsal statüsü ile ilgili konuları, kadın cinselliği ve toplumsal cinsiyet kimliğiyle bir arada harmanlayan kozmetik ve parfüm reklamlarına yönelik farklı düşüncelere sahip kadın yazarlar farklı değerlendirmelere sahiptirler. Moda ve parfüm reklamları üzerine bir çalışmada, kadın bir yazar konuyla ilgili şu saptamayı yapmaktadır: "Sonuç olarak, feminist bir çözümleme parfüm reklamlarının kadın arzularını kontrol ve manipüle etme biçimleri nedeniyle ahlaki açıdan sorgulanabilir olup olmadığını sormalıdır... Ama sadece bu olgudan ötürü, tüketicilerin her nasılsa kapitalist ideolojinin akılsız kurbanları olduğu sonucunu çıkarmamız gerekmemektedir" (Freeland, 2011, s.82). Bu çelişkili durum içinde süren tartışmalar bağlamında, kozmetik reklamlarında kadının özgürleşimi ve kapitalist eril sistem içindeki yeri ile ilgili değerlendirmeler iki uçlu yargılara yol açmaktadır. Bu nedenle değişen sosyo-ekonomik ve kültürel yapının ortaya çıkardığı koşullar içinde, kadının farklı toplumsal cinsiyet konumlarını gösteren yaşam tarzı mizansenlerini ve cinsellik vurgusunu kullanan kozmetik reklamlarındaki kadın temsillerine ilişkin konular geniş bir kuramsal bağlamda tartışılmaya devam etmektedir.

\section{Sonuç}

$\mathrm{Bu}$ çalışma feminist hareketin birinci döneminde yer alan kozmetik reklamlarının görsel tasarımlarında ve metinlerinde yer alan kadın imgelerini toplumsal değişim koşulları içinde ele almıştır. Bu bakımdan, bu çalışmanın daha sonra yapılacak feminist çalışmalar için inceleme alanının topografyasını çıkarma işlevi görmesi de 
amaçlanmıştır. Sonrasında yapılacak çalışmalarda her bir feminist dönem ayrı ayrı ve daha genişletilen bir örneklem grubuyla ele alınabilir. Bu tür çalışmalar, feminist hareketin ortaya çıkardığı kuramsal bağlamın ve toplumsal tepkinin farklı dönemler içinde kozmetik reklamları üzerindeki etkisini daha ayrıntılı bir şekilde gösterecektir. Baskılanmış ve boyun eğdirilmiş kadın temsillerinin kapitalist ideoloji hizmetindeki stereotip sunumlarının eleştirilmesi, toplumda ve reklamcılık sektöründe bu konuda bir duyarlılık kazandırımasını sağlayarak daha özgürleşimci kadın imgelerinin kozmetik reklamlarında yaygınlık kazanmasına katkıda bulunacaktır.

Tarihsel gelişim içinde, kozmetik reklamlarının görsel tasarımlarında kadın bedeni, kapitalist ataerkil kültür içinde belirlenmiş statülerini ve işlevlerini işaret edecek şekilde kullanılagelmiştir. Ancak toplumsal cinsiyete ilişkin olarak toplumsal yapıdaki gelişmelere ve kadının değişen rolüne uygun biçimde, yeni kadın temsilleri de reklamlarda giderek daha fazla yer almaya başlamışlardır. Dolayısıyla, günümüzde geleneksel toplumsal yapılara ait kültürden belirli oranda farklılaşma yaratılmış olsa da, medyadaki söylemlerden yansıyan mesajlar bize kapitalist ataerkil düzenin ve ideolojinin kadın üzerindeki baskısını ve denetimini, yöntem değiştirerek uygulamaya devam ettiğini göstermektedir. Günümüz kadını geçmişe oranla daha özgürdür, ama bu tam bir özgürlük değildir. Çünkü kadın toplumsal yaşam içindeki statüsünü kamusal alanda var olarak yani iş yaşamına girerek arttırmış olsa da, toplumsal imgelem içinde hâlâ geleneksel kadınlık rolleri içinde yer almayı sürdürmek durumundadır.

Bu durum kozmetik reklamlarında da farklı değildir. Özellikle kadın yüzü ve bedenine yönelik mesajları nedeniyle, belirleyici bir toplumsal cinsiyet inşası rolü olan kozmetik reklamlarında kadının geleneksel toplumsal cinsiyet kalıpları içinde sunulması önemli ölçüde devam etmektedir. Yıllar içinde kazanılan tek şey, görece olarak daha geniş cinsel özgürlük sınırlarıdır. Yoksa kadınlar kozmetik reklamlarında yine büyük ölçüde ataerkil ideolojinin arzuları doğrultusunda sunulmaktadırlar. Tüketim olgusuna dayalı kapitalist kültür içinde üretilen kozmetik reklamlarındaki kadın, cinsiyetçi bir söylem içinde bir arzu ve haz nesnesi olarak sunulmaya devam etmektedir. Kadınların daha fazla eğitim ve iş olanaklarına kavuşmaları, toplumsal statülerini yükseltmeleri, medya dünyasında ve akademide daha fazla yer almaları ve kadın hakları savunucularının artması gibi toplumsal yapıda meydana gelen değişimler sonucunda, kozmetik reklamlarında daha güçlü, özgür ve ataerkil kapitalist sistemin koşullamalarından uzaklaşma şansı yakalayabilmiş kadın imgelerinin daha fazla artması mümkün olabilecektir.

\section{Kaynakça}

Addison, h. (2000). Hollywood Consumer Culture, and the Rise of 'Body Shaping'. D. Desser, G. S. Jowett (Ed.). Hollywood Goes Shopping. Minneapolis: University of Minnesota Press.

Catalano, C. (2002). Shaping the American Woman: Feminism and Advertising in 1950s, Constructing the Past. Vol:3. Issue: 1. 45-55. 
Classen, C., Howes, D., Synnott, A. (2003). Aroma: The Cultural History of Smell. New York: Routledge.

Craik, J. (1993). The Face of Fashion: Cultural Studies in Fashion, New York: Routledge.

DeLong, M. R., Bye, E. K. (1990). Apperel for the Senses: The Use and Meaning of Fragrances. Journal of Popular Culture. Vol: 24. Issue: 3. 81-88.

Dyhouse, C. (2013). Glomour: Women, History, Feminism. London: Zed Books.

Freeland, C. A. (2011). Share the Fantasy: Perfume Advertising, Fashion, and Desire, J.Wolfendale, J. Kennett (Ed.). Fashion, Philopsophy for Everyone, Oxford: Blackwell Publishing Ltd.

Funk, R. (2013). Ben ve Biz: Postmodern Insanın Psikanalizi. Ç. Tanyeri (çev.). İstanbul: Yapı Kredi Yayınları.

Gourley, C. (2008). Flappers and the New American Women: Perceptions of Women from 1918 through the 1920s. Minneapolis: Twenty-First Century Books.

Herman, B. (2013). Scent and Subversion: Decoding a Century of Provocative Perfume. Guilford: Lyons Press.

Hesse-Biber, S.N. (2012). Introduction. S. N. Hesse-Biber (Ed.) Handbook of Femisint Research: Theory and Praxis. California: Sage Publications Inc.

Horowitz, D. (1998). Betty Friedan and the Making of the Feminine Mystique: The American Left, The Cold War and Modern Feminism. Amherst: University of Massachussetts Press.

Landers, G. J. B. (1992). The Effect of Social and Economic Changes and Trends in Fashion and Their Effects on International Perfumery Marketing. S. V. Toller, G.H. Dodd, (Ed.).

Fragrance: The Psychology and Biology of Perfume. New York: Elsevier Science Publishers Ltd.

Lather, P. (1991). Getting Smart: Feminist Research and Pedagogy With/in the Postmodern. New York: Routledge.

leiss, W., Kline, S., Jhally, S. (1997). Social Communication in Advertising: Persons, Products and Images of Well Being. New York: Routledge.

Macdonald, M. (2004). From Mrs. Happyman to Kissing Chaps Goodbye: Advertising Reconstructs Feminity. C. Carter, L. Steiner, (Ed.). Critical Readings: Media and Gender, Berkshire: Open University Press.

McAuliffe, M. (2014). Twillight of the Belle Epoque: The Paris of Picasso, Stravinsky, Proust, Renault, Marie Crurie, Gertrude Stein, and Their Friends through the Great War. Maryland: Rowman and Littlefield.

Moreno, J. (2003). Yankee Don't Go Home!: Mexican Nationalism, American Business Culture and the Shaping of Modern Mexico, 1920-1950, London: The University of North Carolina Press.

Murray, D.P. (2017). The Entagled Politis of Feminists, Feminism, Advertising, and Beauty. K. Golombinsky, P. J. Kreshel (Ed.). Feminists, Feminisms, and Advertising: Some Restrictions Apply. Lanham: Lexington Books. 
Özdemir, S. M. (2010). Nitel Veri Analizi: Sosyal Bilimlerde Yöntembilim Sorunsal Üzerine Bir Çalışma. Eskişehir Osmangazi Üniversitesi Sosyal Bilimler Dergisi. 11 (1). 323-343.

Öztan, E. (2016). Feminist Araştırmalar ve Yöntem. F. Saygılıgil (Yay.haz.), Toplumsal Cinsiyet Tartışmaları, Ankara: Dipnot Yayınları.

Peake, L. (2017). Feminism and the Urban. J. R. Short, (Ed.). A Research Agenda for Cities. Cheltenham: Edward Elgar Publishing Ltd.

Rhind, J.P. (2014). Fragrance and Wellbeing: Plant Aromatics and Their Influence on the Pysche. London: Singing Dragon.

Sarıkaya, N. (2007). Özel Bir Tüketici Grubu Olarak Kadınlar. Ö. Torlak, R. Altunışık, Ş. Özdemir (Yay. Haz.). Yeni Müşteri. İstanbul: Hayat Yayıncılık.

Weinbaum, A.E., Thomas, L. M., Ramamurthy, P., Poiger, U. G., Dong, M. Y., Barlow, T.E. (2008). The Modern Girl Around the World: Cosmetics Advertising and the Politics of Race and Style. A. E. Weinbaum, L. M. Thomas, P. Ramamurthy, U. G. Poiger, M. Y. Dong, T. E. Barlow (Ed.), The Modern Girl Around the World: Consumption, Modernity, and Globalization. Durham: Duke University Press.

Zeitz, J. (2006). Flapper: A Madcap Story of Sex, Style, Celebrity, and the Women Who Made America Modern. New York: Three Rivers Press.

Zoonen, L.v. (2004). Feminist Media Studies. London: Sage Publications, 2004. 